\title{
Exploring the Unity Value of Pancasila to Transform Mathematics Contexts in Primary School
}

\author{
Neni Mariana, Julaika, Hendrik Pandu Paksi, Ika Rahmawati \\ Universitas Negeri Surabaya \\ Department of Elementary Teacher Education \\ Surabaya, Indonesia \\ nenimariana@unesa.ac.id
}

\begin{abstract}
The most fundamental principle of Indonesian education is based on Pancasila as the Indonesia's ideology that consists of five valuable precepts. However, the main problem is that Pancasila values are not integrated seriously in other school subjects, including mathematics. People argue that Pancasila is only properly taught in civic education, or its values are only relevant with religion education or social studies. Thus, this study aims to explore possible integration between Pancasila and elementary mathematics education. This paper presents how unity values as the third percept of Pancasila can be excavated to find out mathematical concepts for primary school children. An auto-ethnographic study is used as the main methodology through narrative inquiry of the researcher. Such methods lie on the multi-paradigmatic research design within transformative research. As a result, the exploration exposes some contexts of diversity in Indonesia and colonialism that can be used in mathematics problems. The problems might enhance students understanding of multiculturalism and sense of nationality as well as of mathematical concepts involved.
\end{abstract}

Keywords—values; unity; Pancasila; Context; Mathematics

\section{INTRODUCTION}

Indonesia is a country consisting of islands, where each island is inhabited by different tribe, ethnic, and religion. This situation bears diversity in Indonesia. Diversity usually causes division and disagreement, but not with Indonesia, because the country has Pancasila with the motto "Bhinneka Tunggal Ika" (Unity in Diversity) that means different but still one.

Pancasila is the foundation state of Indonesia that consists of the word panca, which means five, and syiila, which means joints or base. Literally, Pancasila is defined as a foundation with five elements [1]. The five basic elements are the five principles of the Republic of Indonesia. Pancasila has values in accordance with its precepts. The Pancasila values are religious or God value, human value, unity value, people value, and justice value.

The unity value is one of the values contained in the Pancasila precepts. Unity value of Pancasila is important and should be practiced and implemented in daily life both in diverse and multicultural people in Indonesia. Education is media to develop Pancasila values in order to strengthen unity value for Indonesia people. Through education in school, the unity value of Pancasila should be integrated into all subjects at school, not only in civic education, religion education and social studies, but also in mathematics. Most people think that mathematics and Pancasila do not have any connection. Mathematics is about numbers and calculations whereas Pancasila is about human relationships with God and another human.

Actually, mathematics cannot be separated from value. As Ernest [2] argues that social constructivism views mathematics as a product of organized human activity over time. All the different areas of knowledge are human creations, intertwined with their common origins and history. As a result, Mathematics is tied to culture, and is coloured by the value of creators and their cultural context. The value of Ernest referred is an Extrinsic value of Mathematics. Extrinsic value of Mathematics is the values that explicitly serve a particular social/group interest. Thus, Mathematics can be used for the importance of teaching the unity value of Pancasila.

Besides the extrinsic values, Mathematics also has intrinsic values [3]. The intrinsic values of Mathematics are values that already exist naturally when we explore the science of Mathematics. Those values arise when we are studying Mathematics. The implicit concepts of Mathematics contain values. Those values exist with the unity value of Pancasila. Therefore, Mathematics learning can be used to teach unity value which contained in Pancasila.

Based on the description above, there are two subjects presented in this paper:

1) Exploring the unity value as a context of Mathematics learning in Primary School

2) Exploring the unity value contained in Mathematics concept in Primary School

\section{THEORETICAL REVIEW}

\section{A. Unity Value of Pancasila}

The term value is derived from Latin valere, which means useful, capable of being, empowered, applicable. Henceforth, it can be defined as something considered good, beneficial, and most correct according to the belief of a person or a group of people [4]. In a sociology dictionary, value is trustworthiness that exist in an object to satisfy human beings, the nature of an object that causes the interest of a person or group of people 
[5]. So, the value is the essential nature or quality attached to an object. From the definitions of a value can be concluded that a value is a hidden reality, nature or quality inherent in an object that interests and provides benefits and goodness according to the belief of a person or group of people. Like Pancasila which contains the virtues in every its principle, which is believed and agreed upon by the people of Indonesia, and beneficial to them in the life of society, nation and state. One of the unity values that contained in Pancasila is useful to keep the unity and totality of the diverse Indonesian nation or multicultural people.

Since the founding of the nation in 1945, Pancasila has been a topic of philosophical discourse, its content continually re-examined in view of changing social conditions. What makes it distinctive is that it embraces the cultural, ethnic, linguistic and religious diversity of the people as expressed in Indonesia's national motto namely Bhinneka Tunggal Ika (Unity in Diversity). Bhinneka Tunggal Ika (Unity in Diversity) is a valuable basis for intercultural in cultural environments, peace and harmony not only for Indonesia but for the whole of humanity in the world [6]. Bhinneka Tunggal $I \mathrm{ka}$ value is explained on third principle of Pancasila which contained unity value.

Komalasari [7] explains unity of Indonesia precepts contains unity values which indicate that:

1) Unity of Indonesia is the unity of the nation that inhabits the territory of Indonesia

2) The Indonesian nation is the unity of tribes that inhabit the territory of Indonesia

3) The recognition of the "Bhinneka Tunggal Ika" ethnicity and the culture of the nation that gives direction in the fostering of national unity

4) Patriotic values and a nationality sense are a dynamic reality.

\section{B. Mathematics in Primary School}

There are 3 scopes of mathematics in primary school. They are numbers, geometry and measurement, and data processing. Based on three curriculums in Indonesia [8]-[10], these three scopes are explained below:

\section{1) Numbers}

The number matters which learned in primary school are: a) The concept of counting numbers, native numbers and integers, b) Number count operations (counts, integers, and real numbers), c) Comparison of two numbers (bigger, smaller, equal to), d) Placement and symbol of numbers, e) Primes, f) Rome numbers, g) Decimal number, percentage, fractional and counting operations, h) Number patterns, i) Value and equivalence of currency denomination, j) Comparison and scale, k) Numbers of Least Common Multiple (LCM) and Greatest Common Divisor (GCD), 1) Simple powers of numbers, m) Simple square root and cube root numbers, n) Direct and inverse proportion.

\section{2) Geometry and measurement}

Geometry and measurement which learned in primary school are: a) Line segments and relationships of two lines (parallel, intersect, coincide), b) Properties and elements of plane figure, c) Measurement of time, length, weight, speed, discharge, d) Integral equality (time, length, weight), e) Corner measurement, f) The concept of similarity (congruence), g) Tessellation, h) The characteristics of plane reflection, i) Folded symmetry and rotary symmetry, i) Measurement area and perimeter of plane figure (combined and parts), j) Elements of solid figure (side, rib, corner, side diagonal, diagonal space), k) Nets of solid figure, 1) Measuring volume of solid figure, $\mathrm{m}$ ) Cartesian / Coordinates.

\section{Data processing}

Data processing learned in primary school includes: a) Reading the picture diagram, bar chart and pie chart, b) Presenting data in the form of bar charts and pie charts, c) Resolving issues related to bar charts and pie chart, d) Calculating a single data rate, e) Calculating the average data in the table, f) Calculating the average data in the bar chart, g) Calculating the median, mode, highest value and the lowest value of a single data

\section{Relationship of Unity Value of Pancasila with Mathematics}

Mathematics not only learns about numbers and counts, but broader. Numbers are a part of mathematics and it can be a tool of strength when combined with context [3]. Thus, the context of mathematics learning in primary school can be inserted with unity value of Pancasila. The unity value contained in mathematics concept can be taught when learning mathematics.

The unity values which can be used as a context of mathematics learning are about Bhinneka Tunggal Ika for diverse ethnics, tribes, and religions in Indonesia. It can be associated with the addition and subtraction concept. For example, calculating the total of tribes in Indonesia. Patriotic values can be also used as a context of mathematics learning that contained unity value. The unity context mentioned previously includes extrinsic values of mathematics. Extrinsic values of mathematics are the values that explicitly serve a particular social/group interest. Thus, mathematics can be used for teaching the unity value of Pancasila.

Besides the extrinsic value, mathematics also has intrinsic values. The intrinsic values of Mathematics are values that already exist naturally when we explore the science of mathematics. Those values arise when we are studying mathematics. The implicit of mathematics concept contains values. Those values exist with the unity value of Pancasila. Therefore, mathematics learning can be used to teach unity value which contained in Pancasila, for example the direct and inverse proportion concept can be analogized with unity value of Pancasila. So, we explore the unity value from two sides, both from Pancasila values and Mathematics concepts. Exploring the Pancasila values is to develop the unity values as a context in Mathematics learning, while exploring Mathematical concepts is to know the Pancasila values 
intrinsically contained in the concepts. The exploration is illustrated in the schema 1 as follows.

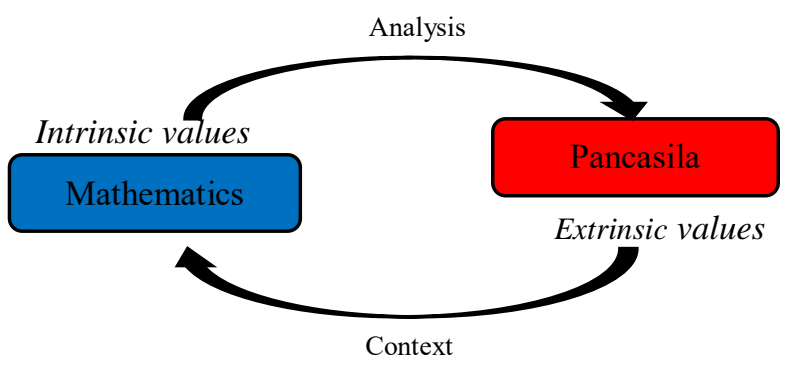

Schema 1. The exploration from both sides

\section{RESEARCH METHODOLOGY}

This research is qualitative research with transformative research. Transformative studies should not use students as the main data, not relate to statistics to process data and get conclusions. The writing style of the transformative research report is freer but remains scientific. Transformative research allows for change (transformation) that begins within the researcher.

Transformative research uses three paradigms (multiparadigms) of relatively new educational research paradigms. They are interpretivism, criticalism, and postmodernism [11]. The application of interpretive paradigm in this research is that the researcher becomes the data of the study. The researcher interprets the unity value of Pancasila that can be explored as the context of mathematics learning, and the unity value of Pancasila that contained in mathematics concept in primary school. The use of critical paradigm is when the researcher is able to empower her/himself and readers to think about changes in practice and policies of better mathematics learning. Meanwhile, implications of the postmodern paradigm in this study are presented in various styles of writing and representations in the research report. The research reports with postmodern paradigms are written freely, data can be represented into stories or narratives, poems and pictures.

The method used to collect data is through study of autoetnography and literature study. Creswell [12] defines autoetnography as "self-reflective and selfexamination by individuals defined in the cultural context". Ellis, Adams, and Bochner [13] describe autoetnography as a research method for exploring personal life experiences in stories/biographies narrated through cultural lenses to make the meaning of complex life in a sociocultural environment. Through an autoetnographic study, Julaika as the researcher became the data in her own research. She reflects on and reconstructs her cultural experiences when becoming a primary school student and as a prospective teacher when doing an internship on the Learning Management Program in a primary school. The experience is Julaika's experience when learning mathematics concepts associated with the unity value of Pancasila. The purpose of the reflection is to transform the context of Mathematics learning, in which most people assume that mathematics is not related to Pancasila values. Data generated from an autoetnographic study of stories, the story is supported by relevant literatures. In order to differentiate them as data, the stories written with different font style. Stories are also supported with images and poetry.

\section{RESULTS AND DISCUSSION}

\section{A. Mathematics Learning with Context of Unity Value of Pancasila in Primary School}

Komalasari [7] explains that the unity value is translated into: Indonesian Unity. It means the unity of Indonesia nation which is the unity of the tribes that inhabit the territory of Indonesia, patriotic values and the sense of nationalism as a dynamic reality. The elaboration of the unity value can be a context in the learning of mathematics in primary school.

The unity value can be a context of mathematics learning for second grade, third grade and fourth grade students in primary school. The unity value that can be used as a context of mathematics learning for second grade students is inserted in the addition and subtraction concept of three numbers. The unity value that can be used as a context of mathematics learning for third grade is inserted in the addition and subtraction concept of four numbers, while in fourth grade is inserted in the Rome numeral concept.

The addition and subtraction concept and the comparisons of the numbers for second grade students in primary school can use the context of many ethnic groups in Indonesia. Students are introduced to the names of tribes in Indonesia, then asked to count how many tribes that exist in Indonesia and compare the number with the total tribes that inhabit every island in Indonesia. The context can be used to present the unity value. Indonesia has islands. Each island is populated with different tribes. Nevertheless, the Indonesian people maintain the unity.

The transformation context of mathematics learning for second grade which contains the unity value of Pancasila can be shown in the following example:

\section{Let's read!}

Indonesia consists of islands.

There are Sumatra, Java, Bali, Borneo, Sulawesi, Maluku and Papua islands.

Each island is populated by different tribes.

Indonesia has many tribes.

More than 1000 tribes exist in Indonesia if examined in detail.

Here are mentioned some tribes whose names are known to inhabit every island.

The island of Sumatra is inhabited by the Aceh tribe, Batak tribe, Caniago tribe, Land tribe, Guci tribe, Forest tribe, Jambi tribe, Karo tribe, Lematang tribe, Mandaling tribe, Malay tribe, Minangkabau tribe, Nias tribe, Orang Laut tribe, Palembang tribe, Riau tribe, Sekah Tamiang tribe and Utan tribe.

Java Island is populated by Bawean tribe, Betawi tribe, Javanese tribe, Kangean tribe, Madurese tribe, Osing tribe, Samin tribe, Sundanese tribe, and Tenggerese tribe. 
Bali Island is populated by Bali Aga tribe and Bali Majapahit tribe.

The tribes that inhabit the Borneo island are Abai tribe, Banjar tribe, Dayak tribe, Iban tribe, Kahayan tribe, Lawangan tribe, Melanau tribe, Ngayu tribe, Ot Danum Punam tribe, Patai tribe, Saputan tribe, Tangalan tribe, Uma Suling tribe.

The tribes on the Sulawesi island include Ampanan tribe, Balatan tribe, Gimpu tribe, Kadipan tribe, Lambatu tribe, Makassar tribe, Pakambia tribe, Rampi tribe, Sadang tribe, Talaud tribe and Wanji tribe.

The Maluku island is inhabited by Alituru tribe, Bacan tribe, Damar tribe, Furuaru tribe, Galela tribe, Halmahera tribe, Kayoa tribe, Loda tribe, Makian tribe, Nila Teun Serui tribe, Patani tribe, Roma Dama tribe, Selaru tribe and Abu tribe.

The tribes inhabiting the Papua island include Asmat tribe, Batanta tribe, Dani tribe, Genyem tribe, Hattam tribe, Sha tribe, Jakui tribe, Kapauku tribe, Mairasi tribe, Numfor tribe, East Coast tribe, Salawati tribe, Gulf Jayapura tribe, and Waigeo tribe.

Although Indonesia consists of islands and tribes, our nation is able to maintain unity.

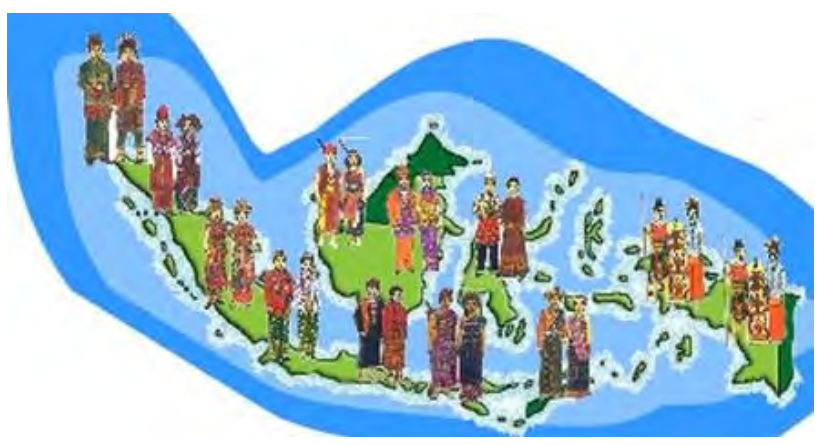

Fig. 1 Tribes of ever island in Indonesia

\section{Let's Practice!}

Answer the following questions based on the text above!

1. How many islands exist in Indonesia? ...

2. How many tribes inhabit Sumatra island?

3. How many tribes inhabit Java island?

4. How many tribes inhabit Bali island? ..

5. How many tribes inhabit Kalimantan island?

6. How many tribes inhabit the Sulawesi island? ...

7. How many tribes inhabit the Maluku island? ...

8. How many tribes inhabit the Papua island? ...

9. How many tribes in Indonesia are mentioned in text above?

10. If the tribes that inhabit Java island do not exist, how many tribes are there in Indonesia? ...

11. If the tribes that inhabit Bali island do not exist, how many tribes are there in Indonesia? ...

12. If tribes in Sumatra and Borneo island join, how many tribes join? ...
13. If the tribes in Maluku and Papua island join, how many tribes join? ...

14. Which island is populated by the largest number of tribes? ...

15. Which tribes inhabit Java island with the Papua island?

16. Compare the following numbers by writing larger, smaller, or equal to the points below.
a. 2 is
rather than 9
b. 18 is $\quad \ldots \quad$ rather than 13
c. 13 is $\quad \ldots \quad$ rather than 11
d. 14 is $\quad \ldots \quad$ rather than 14
e. 9 is $\quad$... $\quad$ rather than 11

From the context of mathematics problems above, we can pick unity value of Pancasila. Although Indonesia nation consists of various tribes, Indonesian people are still able to maintain the unity of the nation. That is because Indonesia has the motto "Bhinnneka Tunggal Ika" (Unity in Diversity) which means different but still one. This shows the unity value. The unity value is contained in the principle of Pancasila, which is in the third principle of Pancasila.

The other unity context which can be used in mathematics learning is a patriotic value. The patriotic value is included in the value of unity contained in the third principle of Pancasila [7]. Patriotic value and national honours such as the struggle of Indonesian nation when was colonized by foreign nations. The Indonesian nation united to fight and expel the colonialist and imperialist from Indonesia. This can be used as a context of mathematics learning for third grade students in primary school about the addition and reduction concept of four numbers. For instance, by calculating the years of colonization of foreign nations.

The transformation context of mathematics learning for third grade which contains the unity value of Pancasila can be shown by the form of mathematics problems below.

\section{Read the following text!}

Foreign Colonization in Indonesia

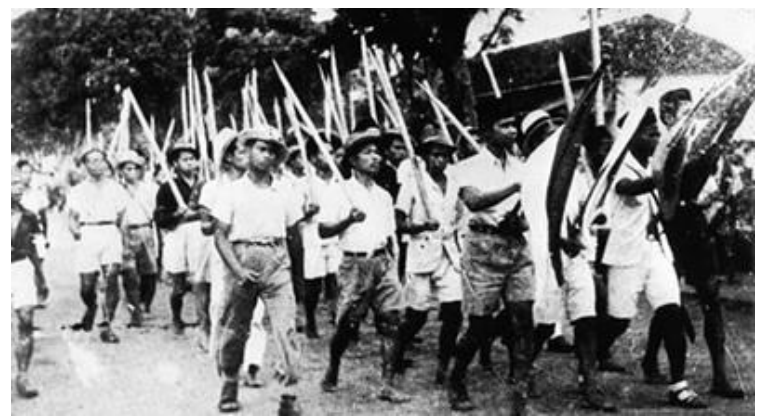

Fig. 2 Indonesian fighters expel colonialis

In ancient times the people of Indonesia suffered because of being controlled by foreigners. That time is called colonial era. The Indonesian nation was forced to work by foreign nations without salaries, so that there was often a famine. They also did not get the proper life and education as they are now. 
For many years, the Indonesian people were colonized by foreign nations. The foreign nation is the Portuguese, Spanish, English, Dutch, and Japanese. The longest was the Dutch nation controlled Indonesia. The foreign nation that first colonized Indonesia was the Portuguese. From 1511 until 1602, the Portuguese colonized Indonesia. Afterward, Indonesian nation was colonized by the Spanish from 1522 until 1529, and then followed by the Dutch who came to Indonesia and colonized Indonesia until 1942. Meanwhile, the British also came to power in Indonesia in 1811. The British ruled Indonesia for 5 years. After we kicked out the Dutch from Indonesia in 1942, Japanese came. Japanese nation colonized Indonesia only for three years then they went from Indonesia.

Indonesian nation is easily colonized by foreigners because of the lack of unity sense and nationalism. During the colonization by foreign nations, the people of Indonesia united to fight. Form of resistance in the form of war and forming organizations. Many Indonesians are killed in the invaders. The nation's heroes struggled and willingly sacrificed to seize independence. Finally, in 1945 Indonesia managed to proclaim or declare independence. The foreign colonizers went from Indonesia.

\section{Answer the following questions based on the text above!}

1. How many years did the Portuguese colonize Indonesia?

2. How many years did the Spanish colonize Indonesia?

3. What year did the last British nation rule Indonesia?

4. How many years did the Dutch colonize Indonesia?

5. What year did Japan go from Indonesia?

6. How long is the time of Indonesia occupied by foreign nations?

7. What nation colonizes the nation of Indonesia the longest?

8. What nation colonizes the Indonesian nation at the very least?

9. Write down the sequence of foreign nations that colonized Indonesia from the shortest time to the longest...

From above example of mathematics problems with patriotic context, we can pick the unity value. Indonesian nation could be colonized by many foreign nations because of the lack of unity sense and nationalism. Thus, the Indonesian nation was easily instigated and lied to by foreign nations. When the Indonesian people united to fight the invaders, and managed to expel the invaders from Indonesia. Therefore, the national unity sense must be maintained, even though we come from different religions, tribes, and races. It is the practice of the unity value which contained in the third principle of Pancasila.

The patriotic context can be also used to mathematics learning for fourth grade student in primary school. It can be embedded into the Rome numeral concept. The patriotic context included such concept is names of sultans who rule Ngayogyakarta Sultanate. Sultans who ruled the first Sultanate until now were given the title of Sri Sultan Hamengkubuwono I to Sri Sultan Hamengkubuwono X. It can be used as a context of mathematics learning in fourth grade to introduce the Rome numerals 1 to 10 . The transformation form of mathematics context for fourth grade which contains the unity value of Pancasila can be demonstrated by the mathematical problems with a story of sultans who rule Ngayogyakarta Sultanate. The fourth-grade students are introduced the patriot moral of Sri Sultan Hamengkubuwono I to X. They learn to read and write Rome numerals I to $\mathrm{X}$, and at the same time they also can learn about unity value of Pancasila.

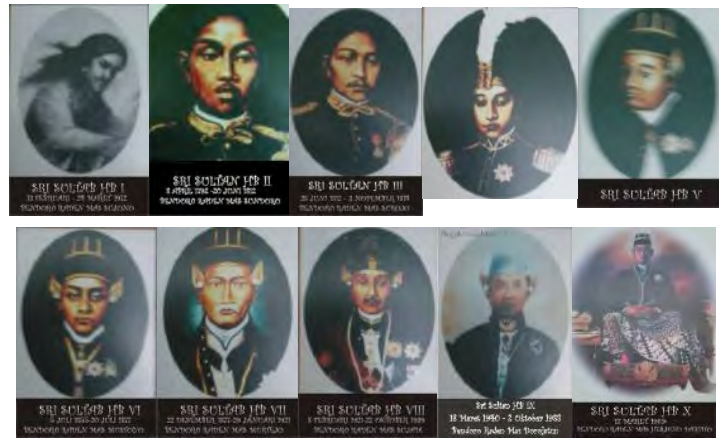

Fig. 3 Sri Sultan Hamengkubuwono I to Sri Sultan Hamengkubuwono X

The unity value which can be picked from Sri Sultan Hamengkubuwono context is Sultan Hamengkubuwono I to IX had the same passion in expelling Dutch colonialism and struggling to get Indonesian independence. With the help of the people and other sultans, they united to fight the colonialist until they succeeded in expelling the Dutch from the Special Territory of Yogyakarta. With such a unity, people could be stronger and successful against the colonialists. Therefore, the national unity sense must be maintained, even though we come from different religions, tribes, and races.

\section{B. The Unity Value of Pancasila which Contained in Mathematics Concept in Primary School}

The unity value can be the context of Mathematics learning in Primary School, otherwise the Mathematics concept in Primary School can also contains the unity value of Pancasila. Mathematics concept that containing the unity value is direct and inverse proportion concept. The unity value that contained in direct and inverse proportion concept is described as follows.

Proportion is the difference between two or more things by following a certain pattern of similarity. The definition of proportion in essence is different but has a similar pattern. In general, the proportion are grouped into two types, namely direct proportion and inverse proportion.

Direct proportion is a ratio of the same value, in which if a component increases then the other components increase as well. Examples of incidents that included in direct proportion is many workers with the results of the work obtained. If more and more workers, then the results of work obtained also more and more.

This is different from the inverse proportion concept. The inverse proportion is the ratio of two or more magnitudes where if a component increases in value, the other components go down in value. Examples of events that included in inverse proportion is the number of workers with the time of 
completion of the work. The more workers, the less time it takes to complete the working.

From the example using the direct proportion and inverse proportion concept can be concluded that to get a maximum job and quickly completed it takes a lot of workers. Work will be completed quickly if it done together. Working together is often called working in mutual cooperation, in Indonesia called gotong royong. Mutual cooperation or gotong royong means working together to achieve the desired result. If we want to do something according to the target and time specified, then we cannot do it alone. To achieve these targets work can be completed by working together. By working together, the work will quickly complete and produce maximum results.

By working together, people will unite and help each other. In fact, people live as social beings in society, so they cannot live without the help of others. In human society always need the help of others, neighbours, friends, or brothers. Therefore, people must always live in a harmony, and maintain unity in the life of society, nation, and state. It is included in the unity value that contained in the third principle of Pancasila. Thus, when teaching the direct and inverse proportion concept, teachers can present the mutual cooperation value and unity value to students.

\section{CONCLUSION}

Mathematics is not only about numbers and counting, but mathematics is also inseparable from value. Mathematics has extrinsic values so that the unity value of Pancasila is possibly inserted into it. Mathematics also has intrinsic values that contains the unity value of Pancasila. The unity value of Pancasila can be used as contexts of mathematics learning in primary school under the contexts of various tribes in Indonesia, patriotic moments during colonialism, and names of Ngayogyakarta sultans. On the other hand, the mathematics concepts of primary school might contain the unity value of Pancasila, for instance the concept of proportion. So, when students learn mathematics in primary school, they can also learn about the unity value. The unity value is essential to be taught for students, because Indonesian students live in multicultural and diverse society in nature. The Indonesian nation consists of various tribes, cultures, races and religions. The urge of fostering a spirit of the unity value is to keep the unity of the nation, so as not to arise disputes and divisions between nations.

\section{References}

[1] D. Siswoyo, "Philosophy of education in Indonesia: Theory and thoughts of institutionalized state (PANCASILA)," Asian Soc. Sci., vol. 9, no. 12, p. 136, 2013.

[2] P. Ernest, Philosophy Mathematics Educ. Routledge, 2013.

[3] M. Neni, "Transforming Mathematics Problems in Indonesian Primary Schools By Embedding Islamic and Indonesian Contexts." Disertasi. Perth Australia: Murdoch University, 2017.

[4] M. W. Frame, "The challenges of intercultural marriage: Strategies for pastoral care,” Pastoral Psychol., vol. 52, no. 3, pp. 219-232, 2004

[5] J. Scott and G. Marshall, A dictionary of sociology. Oxford University Press, USA, 2009.

[6] D. Butler, "Peace and Harmony in the World Based on Pancasila and Bhinneka Tunggal Ika (Unity in Diversity)," Harmoni, vol. 15, no. 2, pp. 33-40, 2016.

[7] K. Komalasari, "Pendidikan Pancasila," Surabaya: Lentera Cendekia, 2007.

[8] D. P. Nasional, "Kurikulum Tingkat Satuan Pendidikan.” Jakarta: Depdiknas, 2006.

[9] M. Nuh, "Kurikulum 2013," Sumber http//www. kemdiknas. go. id, 2013.

[10] P. No, “Tahun 2016 Tentang Kompetensi Inti dan Kompetensi Dasar Pelajaran Pada Kurikulum 2013," Jakarta: Permendikbud, 24AD.

[11] P. C. Taylor and M. N. D. Medina, "Educational research paradigms: From positivism to multiparadigmatic," J. Meaning-Centered Educ., vol. 1 , no. 2 , pp. $1-13,2013$.

[12] J. W. Creswell, Educational research: Planning, conducting, and evaluating quantitative and qualitative research. 2012

[13] C. Ellis, T. E. Adams, and A. P. Bochner, "Autoethnography: An overview," Historical Social Research. 2011. 